\title{
Racism: the shameful practices that the medical profession is finally addressing
}

\author{
Sherri-Ann M. Burnett-Bowie ${ }^{1 *}$ (I) and Gloria A. Bachmann²
}

Keywords: Discrimination, Racism, Bias, Interpersonal racism, Structural racism, Social determinants of health, Incarceration, SWAN study, WHI, Asian, African American, Black, Indigenous, Hispanic, Latinx, BIPOC

Black Americans represent 13.4\% of the United States (US) population but only $3.6 \%$ of US medical school faculty $[1,2]$. This inequity is due to different manifestations of structural racism, which include disparities in early education opportunities; high cost of undergraduate and medical education; income inequities that make it challenging to pursue medical school or remain in academia; and bias that is experienced by students, trainees, and faculty [3-6]. Disturbing inequities also exist in life expectancies in the US. Even though population level differences in life expectancy between Black and White Americans have been decreasing, certain regions have experienced increasing differences in life expectancy [7]. Specifically, in the last two decades the difference in life expectancy between Black and White Americans living in Washington, DC has increased. In 2016, non-Hispanic Black men residing in Washington, DC lived 17.2 years less than non-Hispanic White men, and non-Hispanic Black women lived 12.1 years less than non-Hispanic White women [7]. Notably, these stark racial differences in life expectancy were predominantly due to differences in heart disease, cancer, and homicide (the latter being for men only with the differences decreasing over time) [7]. Increased tobacco use, decreased physical activity, and obesity contribute to heart disease and cancer and are manifestations of structural racism. Tobacco companies advertise more in communities of color, and many

\footnotetext{
*Correspondence: sburnett-bowie@mgh.harvard.edu

${ }^{1}$ Endocrine Division, Department of Medicine, Massachusetts General Hospital and Harvard Medical School, 50 Blossom Street, Thier 1051, Boston, MA 02114-2696, USA

Full list of author information is available at the end of the article
}

communities of color are unable to engage in regular physical activity because of limited recreational time, lack of green space, or unsafe neighborhoods [8-11]. This special thematic series of Women's Midlife Health, Structural Racism and Midlife Health, focuses on structural racism and midlife health. This topic is particularly relevant now given the ongoing focus on social justice and the growing appreciation of the impact of racism in both society and healthcare. This series includes a review of the Study of Women's Health Across the Nation (SWAN) by Lewis et al, which describes disparities in midlife health in Black and White women; a review of the guidelines from the Women's Health Initiative (WHI) on the use of race/ethnicity data by Garcia et al, which provides a framework on the importance of designing studies that are inclusive of all populations, that use appropriate terminology, and that collect the data that race/ethnicity may be a proxy for, e.g. social determinants of health variables; a review by Diop et al that provides important frameworks and language on discussing discrimination with patients [12]; a review by Hutchinson-Colas et al discussing how incarceration impacts women's health; and an interview with Dr. Vivian Pinn, the first director of the Office of Research of Women's Health at the National Institutes of Health.

Structural racism refers to "processes of racism that are embedded in laws, policies, and practices of society and its institutions that provide advantages to racial groups deemed as superior, while differentially oppressing, disadvantaging, or otherwise neglecting racial groups viewed as inferior" [13]. Structural racism reflects the multiple and reinforcing ways in which societies facilitate

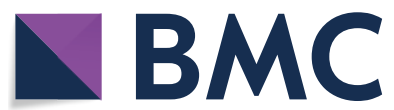

(c) The Author(s) 2021. Open Access This article is licensed under a Creative Commons Attribution 4.0 International License, which permits use, sharing, adaptation, distribution and reproduction in any medium or format, as long as you give appropriate credit to the original author(s) and the source, provide a link to the Creative Commons licence, and indicate if changes were made. The images or other third party material in this article are included in the article's Creative Commons licence, unless indicated otherwise in a credit line to the material. If material is not included in the article's Creative Commons licence and your intended use is not permitted by statutory regulation or exceeds the permitted use, you will need to obtain permission directly from the copyright holder. To view a copy of this licence, visit http://creativecommons.org/licenses/by/4.0/. The Creative Commons Public Domain Dedication waiver (http://creativeco mmons.org/publicdomain/zero/1.0/) applies to the data made available in this article, unless otherwise stated in a credit line to the data. 
racial discrimination through many systems, including housing, education, employment, healthcare, and criminal system practices [3]. These practices lead to discriminatory beliefs, behaviors, and resource allocation; specifically, access to goods, services, and opportunities that are influenced by an individual's race [3]. Furthermore, structural racism reflects the codifying of these inequities into organizational practice and policy, such that they become the norm. While there has been appropriate focus on discriminatory behaviors that are mediated at the individual level (personally-mediated racism), there needs to be similar focus on structural or institutional racism, as well as internalized racism, which occurs when individuals accept negative beliefs about their abilities and value [14]. Given that structural or institutional racism results in inequitable distribution of resources and opportunities and most of health is determined by social determinants [15], it is imperative that healthcare providers are part of the coalition addressing structural racism.

In education, research, and clinical practice domains, we should be considering how racism, in any of its forms, is at play [16]. When educating future nurses, physicians, and other advanced care providers, we should understand that clinical images must be representative of the diverse populations whom we serve and that race should not be conflated with ancestry [17-19]. Furthermore, we should understand that race is not a risk factor for disease but a proxy for exposure to racism. Thus, our clinical algorithms which include race and in so doing potentially harm vulnerable populations by reducing our ability to diagnose disease should be re-evaluated [20-22]. Similarly, we should be educating about and creating systems to address provider held unconscious bias, which the National Academy of Medicine identified as one of the three root causes of racial and ethnic health disparities, limited access to care and lack of trust in the healthcare system being the other two [23]. Finally, given the deleterious impact of racism or discrimination on health, we should be creating safe spaces for patients to discuss their experiences using a trauma-informed lens. The diversity of research study populations is paramount to ensuring the generalizability of findings [24]. Moreover, investigation also has the potential to advance anti-racism by highlighting and studying the factors that lead to differences in health outcomes (e.g., socioeconomic status or education) versus adjusting for those factors. By placing the spotlight on the connections between social determinants of health or racism and health outcomes, clinical and translational investigators can transform how we understand health and disease considerably [25, 26]. To that end, as the harmful effect of discrimination on health, as measured by allostatic load [27-33], is increasingly recognized, all investigators should consider using metrics like the Everyday Discrimination Scale, as it provides a mechanism by which to examine racism [34-36].

The influence of social determinants of health and/or racism on health and wellness can be invisible because of the pervasiveness and longstanding nature of inequity [37-39]. Social determinants of health are the conditions in which individuals are born, live, learn, work, and play, and their associated health impacts [40-42]. Differences in social determinants are linked to wealth status and drive the powerful association between a person's zip code and their life expectancy $[16,43]$. These conditions, operating across the socioecological spectrum of human life, are influenced by socioeconomic status and by levels of racism. Specific examples of influencers include housing conditions, school quality, environmental conditions, employment opportunities, access to healthy food, and access to quality healthcare, all of which may be influenced by racial inequities [44]. Social determinants of health moderate the downstream biological processes responsible for health outcomes. The disproportionate impact of COVID-19 disease on Asian, Black, Indigenous, and Latinx people reflects longstanding differences in the social determinants of health and the effects of structural racism [45-55]. Health equity (which is the customized distribution of resources and opportunities across a population to ensure no subset of groups is at a particular advantage), not equality (which is the distribution of the same resources and opportunities to every individual across a population), must be our goal $[56,57]$. By way of example, let's consider our approach to two individuals, one who is chronically malnourished with very low body mass index (BMI) and one who has normal BMI. If we give both individuals the same $2000 \mathrm{cal} /$ day diet for 1 week (equality), the chronically malnourished person may improve somewhat but will still languish relative to the normal BMI person. However, if the chronically malnourished individual is given customized meals, with potentially more calories or protein, which differ from the normal BMI person's nutrition (equity), they will both be positioned to achieve health. Similarly, health equity which addresses the longstanding inequity that has been perpetuated through structural racism and manifests as social determinants of health, should be the focus of our health systems [58, 59].

To progress towards health equity, members of health systems must understand our roles in combatting structural racism [3, 60-64]. To date, the medical profession has not fully acknowledged the history of inequality or bias in medicine and science, which includes the adverse impact of medical racism on BIPOC (Black, Indigenous and People of Color) patients; the 
continuing negative impact on medical professionals, including BIPOC trainees and staff; and the negative implications on healthcare's missions of patient care, education, and research [4, 6, 23, 37, 65-73]. Medicine also must publicly acknowledge the unethical research that has been carried out on BIPOC individuals, such as the research-driven gynecological surgeries that J Marion Sims performed on enslaved Black women, including Anarcha Westcott, without their consent or proper anesthesia $[74,75]$. Structural racism is embedded and reinforced in medicine's policies, practices, cultural representations, and norms. Importantly, examples of structural or interpersonal racism, including microaggressions, in science and medicine are increasingly being discussed, which is essential to addressing the invisibility of the problem [76-81].

Currently there is considerable momentum towards addressing structural racism. The diversity, equity, and inclusion (DEI) initiatives that are in development in all major sectors of society (including economic, educational, and health) are pathways to meaningful progress in both eliminating structural and interpersonal racism and promoting health and wellness for all individuals $[16,37,46,48,82]$. Despite any associated discomfort, every individual in healthcare delivery, research, education, and administration must feel responsible for directly responding to identified situations of structural or interpersonal racism, challenge currently accepted norms, and advocate for changed policies and procedures. Change will require that we re-evaluate all institutional, state, and federal policies and procedures from an anti-racism/equity lens. This includes how we care for patients, how we educate, and how we mentor those early in career. Additionally, we must appreciate that opportunities are not equally available to all and that race and gender unfairly influence too many outcomes, whether that be a limb preserving procedure, a potentially lifesaving test, or a professional opportunity [83-87]. Knowledge about these inequities is fundamental, in addition there must be authentic individual and institutional commitment to change. We all need shared frameworks to discuss these painful realities, as well as training on how to recognize and respond to both structural and interpersonal racism. Finally, we all need to feel empowered to catalyze the change that is needed to achieve excellence through equity.

\footnotetext{
Abbreviations

SWAN: Study of Women's Health Across the Nation; WHI: Women's Health Initiative; US: United States.
}

Acknowledgments

Not applicable.
Authors' contributions

SMB and GAB wrote and edited the manuscript. Both authors read and approved the final manuscript.

\section{Funding}

Not applicable.

Availability of data and materials

Not applicable.

\section{Declarations}

Ethics approval and consent to participate

Not applicable.

\section{Consent for publication}

Not applicable.

\section{Competing interests}

SM Burnett-Bowie and GA Bachmann are Guest Editors for this special series on Structural Racism. As per the journal policy, peer review, and all decisions regarding the manuscript were handled by the Editor from a different institution, and SM Burnett-Bowie and GA Bachmann were blinded to the peer review.

\section{Author details}

${ }^{1}$ Endocrine Division, Department of Medicine, Massachusetts General Hospital and Harvard Medical School, 50 Blossom Street, Thier 1051, Boston, MA 02114-2696, USA. ${ }^{2}$ Women's Health Institute, Rutgers Robert Wood Johnson Medical School, New Brunswick, NJ, USA.

Received: 24 August 2021 Accepted: 14 October 2021

Published online: 02 November 2021

\section{References}

1. American Association of Medical Colleges. Percentage of full-time U.S. medical school facutly by race/ethnicity, 2018; 2018. Available from: https://www.aamc.org/data-reports/workforce/interactive-data/figure15-percentage-full-time-us-medical-school-faculty-race/ethnicity-2018

2. US Census Bureau. 2019 [Available from: https://www.census.gov/quick facts/fact/table/US/RHI225219.

3. Bailey ZD, Krieger N, Agénor M, Graves J, Linos N, Bassett MT. Structural racism and health inequities in the USA: evidence and interventions. Lancet. 2017;389(10077):1453-63.

4. Osseo-Asare A, Balasuriya L, Huot SJ, Keene D, Berg D, Nunez-Smith $M$, et al. Minority resident Physicians' views on the role of race/ethnicity in their training experiences in the workplace. JAMA Netw Open. 2018;1(5):e182723.

5. Brownlee D. Why are Black Male Doctors Still so Scarce in America? Forbes; 2020 [Available from: https://www.forbes.com/sites/danabrownl ee/2020/08/11/why-are-black-male-doctors-still-so-scarce-in-america/? $\mathrm{sh}=5 \mathrm{c} 677 \mathrm{~d} 3127 \mathrm{c} 2$.

6. Serafini K, Coyer C, Brown Speights J, Donovan D, Guh J, Washington J, et al. Racism as experienced by physicians of color in the health care setting. Fam Med. 2020;52(4):282-7.

7. Roberts M, Reither EN, Lim S. Contributors to the black-white life expectancy gap in Washington D.C. Sci Rep. 2020;10(1):13416.

8. Kirchner TR, Villanti AC, Cantrell J, Anesetti-Rothermel A, Ganz O, Conway $\mathrm{KP}$, et al. Tobacco retail outlet advertising practices and proximity to schools, parks and public housing affect Synar underage sales violations in Washington, DC. Tob Control. 2015;24(e1):e52-8.

9. Wen M, Zhang X, Harris CD, Holt JB, Croft JB. Spatial disparities in the distribution of parks and green spaces in the USA. Ann Behav Med. 2013;45 Suppl 1(Suppl 1):S18-27.

10. Deka D, Brown CT, Sinclair J. Exploration of the effect of violent crime on recreational and transportation walking by path and structural equation models. Health Place. 2018;52:34-45. 
11. Mathis AL, Rooks RN, Tawk RH, Kruger DJ. Neighborhood influences and BMI in urban older adults. J Appl Gerontol. 2017;36(6):692-708.

12. Diop MS, Taylor CN, Murillo SN, Zeidman JA, James AK, Burnett-Bowie SM. This is our lane: talking with patients about racism. Womens Midlife Health. 2021;7(1):7.

13. Williams DR, Lawrence JA, Davis BA. Racism and health: evidence and needed research. Annu Rev Public Health. 2019:40:105-25.

14. Jones CP. Levels of racism: a theoretic framework and a gardener's tale. Am J Public Health. 2000:90(8):1212-5.

15. Office of Disease Prevention and Health Promotion. Healthy People 2020: Social Determinants of Health [cited 2021. Available from: https://www. healthypeople.gov/2020/topics-objectives/topic/social-determinan ts-of-health.

16. Churchwell K, Elkind MSV, Benjamin RM, Carson AP, Chang EK, Lawrence W, et al. Call to action: structural racism as a fundamental driver of health disparities: a presidential advisory from the American Heart Association. Circulation. 2020;142(24):e454-e68.

17. Smedley A, Smedley BD. Race as biology is fiction, racism as a social problem is real: anthropological and historical perspectives on the social construction of race. Am Psychol. 2005:60(1):16-26.

18. Yudell M, Roberts D, DeSalle R, Tishkoff S. SCIENCE AND SOCIETY. Taking race out of human genetics. Science. 2016;351(6273):564-5.

19. Nolen L. How medical education is missing the Bull's-eye. N Engl J Med. 2020;382(26):2489-91.

20. Vyas DA, Eisenstein LG, Jones DS. Hidden in plain sight - reconsidering the use of race correction in clinical algorithms. N Engl J Med. 2020;383(9):874-82.

21. Vyas DA, Jones DS, Meadows AR, Diouf K, Nour NM, Schantz-Dunn J. Challenging the use of race in the vaginal birth after cesarean section calculator. Womens Health Issues. 2019;29(3):201-4.

22. Norris KC, Eneanya ND, Boulware LE. Removal of race from estimates of kidney function: first. Do No Harm Jama. 2021;325(2):135-7.

23. Institute of Medicine (US) Committee on Understanding and Eliminating Racial and Ethnic Disparities in Health Care. Washington (DC): Nationa Academies Press (US); 2003.

24. Mapes BM, Foster CS, Kusnoor SV, Epelbaum MI, AuYoung M, Jenkins G, et al. Diversity and inclusion for the all of us research program: a scoping review. PLoS One. 2020;15(7):e0234962.

25. Boyd RW, Lindo EG, Weeks LD, McLemore MR. Health affairs blog; 2020. [cited 2021]

26. Purnell TS, Simpson DC, Callender CO, Boulware LE. Dismantling structural racism as a root cause of racial disparities in COVID-19 and transplantation. Am J Transplant. 2021;21(7):2327-32.

27. Berger M, Sarnyai Z. "more than skin deep": stress neurobiology and mental health consequences of racial discrimination. Stress. 2015;18(1):1-10.

28. Upchurch DM, Stein J, Greendale GA, Chyu L, Tseng CH, Huang MH, et al. A longitudinal investigation of race, socioeconomic status, and psychosocial mediators of Allostatic load in midlife women: findings from the study of Women's health across the nation. Psychosom Med. 2015;77(4):402-12.

29. Tuggle AC, Cohen JH, Crews DE. Stress, migration, and allostatic load: a model based on Mexican migrants in Columbus, Ohio. J Physiol Anthropol. 2018;37(1):28.

30. Cuevas AG, Wang K, Williams DR, Mattei J, Tucker KL, Falcon LM. The association between perceived discrimination and Allostatic load in the Boston Puerto Rican health study. Psychosom Med. 2019;81 (7):659-67.

31. Thomas MD, Michaels EK, Reeves AN, Okoye U, Price MM, Hasson RE, et al. Differential associations between everyday versus institution-specific racial discrimination, self-reported health, and allostatic load among black women: implications for clinical assessment and epidemiologic studies. Ann Epidemiol. 2019;35:20-8.e3.

32. Williams DR, Lawrence JA, Davis BA, Vu C. Understanding how discrimination can affect health. Health Serv Res. 2019;54 Suppl 2(Suppl 2):1374-88.

33. Cave L, Cooper MN, Zubrick SR, Shepherd CCJ. Racial discrimination and allostatic load among first nations Australians: a nationally representative cross-sectional study. BMC Public Health. 2020;20(1):1881.

34. Shariff-Marco S, Breen N, Landrine H, Reeve BB, Krieger N, Gee GC, et al. MEASURING EVERYDAY RACIAL/ETHNIC DISCRIMINATION IN HEALTH SURVEYS: how best to ask the questions, in one or two stages, across multiple racial/ethnic groups? Du Bois Rev. 2011;8(1):159-77.
35. Beatty DL, Matthews KA, Bromberger JT, Brown C. Everyday discrimination prospectively predicts inflammation across 7 -years in racially diverse midlife women: study of Women's health across the nation. J Soc Issues. 2014;70(2):298-314.

36. Moody DLB, Chang YF, Pantesco EJ, Darden TM, Lewis TT, Brown C, et al. Everyday discrimination prospectively predicts blood pressure across 10 years in racially/ethnically diverse midlife women: study of Women's health across the nation. Ann Behav Med. 2019;53(7):608-20.

37. deShazo RD, Hoesley CJ, Vickers SM.Ending Racial Bias in American Medicine: A Call for Help from the AMA, NMA, AAMC, and the Rest of Us. Am J Med. 2021;134(5):565-8. https://doi.org/10.1016/j.amjmed.2020.11.011. Epub 2020 Dec 11. PMID: 33316252 Review.

38. Sember R, Fullilove MT, Fullilove RE. What we "cannot not know in America": 400 years of inequality and seven sins. Front Public Health. 2021;9:678053.

39. Sloane PD, Yearby R, Konetzka RT, Li Y, Espinoza R, Zimmerman S. Addressing systemic racism in nursing homes: a time for action. J Am Med Dir Assoc. 2021;22(4):886-92.

40. Jones CP, Jones CY, Perry GS, Barclay G, Jones CA. Addressing the social determinants of children's health: a cliff analogy. J Health Care Poor Underserved. 2009;20(4 Suppl):1-12.

41. Penman-Aguilar A, Talih M, Huang D, Moonesinghe R, Bouye K, Beckles G. Measurement of health disparities, health inequities, and social determinants of health to support the advancement of health equity. J Public Health Manag Pract. 2016;22 Suppl 1(Suppl 1):S33-42.

42. Spruce L. Back to basics: social determinants of health. AORN J. 2019;110(1):60-9.

43. Braveman P, Egerter S, Williams DR. The social determinants of health: coming of age. Annu Rev Public Health. 2011;32:381-98.

44. Thornton RL, Glover CM, Cené CW, Glik DC, Henderson JA, Williams DR. Evaluating strategies for reducing health disparities by addressing the social determinants of health. Health Aff (Millwood). 2016;35(8):1416-23.

45. Gross CP, Essien UR, Pasha S, Gross JR, Wang SY, Nunez-Smith M. Racial and ethnic disparities in population-level Covid-19 mortality. J Gen Intern Med. 2020;35(10):3097-9.

46. Johnson-Agbakwu CE, Ali NS, Oxford CM, Wingo S, Manin E, Coonrod DV. Racism, COVID-19, and Health Inequity in the USA: a Call to Action. J Racial Ethn Health Disparities. 2020:1-7. https://doi.org/10.1007/s40615020-00928-y. Online ahead of print. PMID: 33197038 Free PMC article. Review.

47. Egede LE, Walker RJ. Structural racism, social risk factors, and Covid19 - a dangerous convergence for black Americans. N Engl J Med. 2020;383(12):e77.

48. Krieger N. ENOUGH: COVID-19, structural racism, police brutality, plutocracy, climate change-and time for health justice, democratic governance, and an equitable, sustainable future. Am J Public Health. 2020;110(11):1620-3.

49. Essien UR, Corbie-Smith G. Opportunities for improving population health in the post-COVID-19 era. J Hosp Med. 2021;16(1):53-5.

50. Dickinson KL, Roberts JD, Banacos N, Neuberger L, Koebele E, BlanchHartigan D, et al. Structural racism and the COVID-19 experience in the United States. Health Secur. 2021;19(S1):S14-s26.

51. Reinhart E, Chen DL. Carceral-community epidemiology, structural racism, and COVID-19 disparities. Proc Natl Acad Sci U S A. 2021;118(21):e2026577118. https://doi.org/10.1073/pnas.2026577118. PMID: 33972409.

52. Lopez L III, Hart LH III, Katz MH. Racial and ethnic health disparities related to COVID-19. JAMA. 2021;325(8):719-20.

53. Yan BW, Hwang AL, Ng F, Chu JN, Tsoh JY, Nguyen TT. Death toll of COVID19 on Asian Americans: disparities revealed. J Gen Intern Med. 2021:1-5.

54. Williams DR. African-American health: the role of the social environment. J Urban Health. 1998;75(2):300-21.

55. Ahmed AT, Mohammed SA, Williams DR. Racial discrimination \& health: pathways \& evidence. Indian J Med Res. 2007;126(4):318-27.

56. Kurapati S, Schaumburg IL. American Medical Women's Association; 2020. [cited 2021]. Available from: https://www.amwa-doc.org/health-equal ity-vs-health-equity/

57. MPH@GW. Equity vs. equality: What's the difference? Washington, DC: The George Washington University online Master of Public Health program; 2020. Available from: https://onlinepublichealth.gwu.edu/resources/ equity-vs-equality/ 
58. Gottlieb L, Fichtenberg C, Alderwick H, Adler N. Social determinants of health: What's a healthcare system to do? I Healthc Manag. 2019;64(4):243-57.

59. Lathrop B. Moving toward health equity by addressing social determinants of health. Nurs Womens Health. 2020;24(1):36-44.

60. Feagin J, Bennefield Z. Systemic racism and U.S. health care. Soc Sci Med. 2014;103:7-14.

61. Hardeman RR, Medina EM, Kozhimannil KB. Structural racism and supporting black lives - the role of health professionals. N Engl J Med. 2016;375(22):2113-5.

62. Mateo CM, Williams DR. Addressing bias and reducing discrimination: the professional responsibility of health care providers. Acad Med. 2020;95(12S Addressing Harmful Bias and Eliminating Discrimination in Health Professions Learning Environments):S5-s10.

63. Serchen J, Doherty R, Atiq O, Hilden D. A comprehensive policy framework to understand and address disparities and discrimination in health and health care: a policy paper from the American college of physicians. Ann Intern Med. 2021

64. Yousif $H$, Ayogu N, Bell T. The path forward - an antiracist approach to academic medicine. N Engl J Med. 2020;383(15):e91.

65. Sivashanker K, Couillard C, Goldsmith J, Walker N, Eappen S. Addressing the caste system in U.S. healthcare in the era of COVID-19. Int J Equity Health. 2020;19(1):184.

66. Power-Hays A, McGann PT. When actions speak louder than words - racism and sickle cell disease. N Engl J Med. 2020;383(20):1902-3.

67. Goddu AP, O'Conor KJ, Lanzkron S, Saheed MO, Saha S, Peek ME, et al. Correction to: do words matter? Stigmatizing language and the transmission of bias in the medical record. J Gen Intern Med. 2019;34(1):164.

68. Torres MB, Salles A, Cochran A. Recognizing and reacting to microaggressions in medicine and surgery. JAMA Surg. 2019;154(9):868-72.

69. Ackerman-Barger K, Boatright D, Gonzalez-Colaso R, Orozco R, Latimore $D$. Seeking inclusion excellence: understanding racial microaggressions as experienced by underrepresented medical and nursing students. Acad Med. 2020;95(5):758-63.

70. Chisholm LP, Jackson KR, Davidson HA, Churchwell AL, Fleming AE, Drolet $B C$. Evaluation of racial microaggressions experienced during medical school training and the effect on medical student education and burnout: a validation study. J Natl Med Assoc. 2021;113(3):310-4.

71. Sudol NT, Guaderrama NM, Honsberger P, Weiss J, Li Q, Whitcomb EL. Prevalence and nature of sexist and racial/ethnic microaggressions against surgeons and anesthesiologists. JAMA Surg. 2021;156(5):e210265.

72. Anderson N, Lett E, Asabor EN, Hernandez AL, Nguemeni Tiako MJ, Johnson C, et al. The Association of Microaggressions with depressive symptoms and institutional satisfaction among a National Cohort of medical students. J Gen Intern Med. 2021.

73. Lawrence JA, Davis BA, Corbette T, Hill EV, Williams DR, Reede JY. Racial/ ethnic differences in burnout: a systematic review. J Racial Ethn Health Disparities. 2021:1-13.
74. Kaupp-Roberts S. Out of the shadows: the legacy of racism in obstetrics and gynaecology. Bmj. 2020;371:m4675.

75. Khabele D, Holcomb K, Connors NK, Bradley L. A perspective on James Marion Sims, MD, and Antiblack racism in obstetrics and gynecology. J Minim Invasive Gynecol. 2021;28(2):153-5.

76. Sue DW, Capodilupo CM, Torino GC, Bucceri JM, Holder AM, Nadal KL, et al. Racial microaggressions in everyday life: implications for clinical practice. Am Psychol. 2007;62(4):271-86.

77. Walls ML, Gonzalez J, Gladney T, Onello E. Unconscious biases: racial microaggressions in American Indian health care. J Am Board Fam Med. 2015;28(2):231-9.

78. Snyder CR, Wang PZ, Truitt AR. Multiracial patient experiences with racial microaggressions in health care settings. J Patient Cent Res Rev. 2018:5(3):229-38.

79. Cruz D, Rodriguez Y, Mastropaolo C. Perceived microaggressions in health care: a measurement study. PLoS One. 2019;14(2):e0211620.

80. Molina MF, Landry Al, Chary AN, Burnett-Bowie SM. Addressing the elephant in the room: microaggressions in medicine. Ann Emerg Med. 2020;76(4):387-91.

81. Miller $L R$, Peck $B M$. A prospective examination of racial microaggressions in the medical encounter. J Racial Ethn Health Disparities. 2020;7(3):519-27.

82. Trent M, Dooley DG, Dougé J. The impact of racism on child and adolescent health. Pediatrics. 2019;144(2).

83. Schulman KA, Berlin JA, Harless W, Kerner JF, Sistrunk S, Gersh BJ, et al. The effect of race and sex on physicians' recommendations for cardiac catheterization. N Engl J Med. 1999;340(8):618-26.

84. Dovidio JF, Gaertner SL. Aversive racism and selection decisions: 1989 and 1999. Psychol Sci. 2000;11(4):315-9.

85. Collins TC, Johnson M, Henderson W, Khuri SF, Daley J. Lower extremity nontraumatic amputation among veterans with peripheral arterial disease: is race an independent factor? Med Care. 2002;40(1 Suppl):1106-16.

86. Moss-Racusin CA, Dovidio JF, Brescoll VL, Graham MJ, Handelsman J. Science faculty's subtle gender biases favor male students. Proc Natl Acad Sci U S A. 2012;109(41):16474-9.

87. Hagiwara N, Penner LA, Gonzalez R, Eggly S, Dovidio JF, Gaertner SL, et al. Racial attitudes, physician-patient talk time ratio, and adherence in racially discordant medical interactions. Soc Sci Med. 2013;87:123-31.

\section{Publisher's Note}

Springer Nature remains neutral with regard to jurisdictional claims in published maps and institutional affiliations.
Ready to submit your research? Choose BMC and benefit from:

- fast, convenient online submission

- thorough peer review by experienced researchers in your field

- rapid publication on acceptance

- support for research data, including large and complex data types

- gold Open Access which fosters wider collaboration and increased citations

- maximum visibility for your research: over $100 \mathrm{M}$ website views per year

At BMC, research is always in progress.

Learn more biomedcentral.com/submissions 